\title{
Subcellular localization of immunoreactive oxytocin within thymic epithelial cells of the male mouse
}

\author{
Martin Wiemann, Günter Ehret \\ Abteilung Vergleichende Neurobiologie, Universität Ulm, Oberer Eselsberg M25/5, W-7900 Ulm, Germany
}

Received: 30 September 1992/Accepted: 15 December 1992

\begin{abstract}
Immunoreactive oxytocin is expressed by thymic epithelial cells, which share properties with neuroendocrine cells. In order to investigate the assumed paracrine secretion of oxytocin, we studied the subcellular localization of immunoreactive oxytocin within thymic tissue and cultured thymic epithelial cells of the male mouse. Three types of immunoreactive cells were distinguished with the electron microscope. Immunoreactive oxytocin was found to be restricted to the cytoplasm by the use of pre- and postembedding methods. Some epithelial cells, especially in the cortex, showed a pronounced labelling of vesicular membranes and membrane tubules of the endoplasmic reticulum. In some cells, keratin filaments were associated with the electrondense stain. Under culture conditions immunoreactive cells of different shapes were found, all displaying similar patterns of labelling. The contents of different types of vacuoles were only rarely labelled. A special class of immunoreactive exocytotic vesicles could not be identified. Thus, our results do not support neuroendocrine secretion of oxytocin via vesicles of thymic epithelial cells but offer alternative modes of secretion.
\end{abstract}

Key words: Thymus - Epithelial cells - Oxytocin - Immunocytochemistry - Paracrine secretion - Mouse (NM$\mathrm{RI)}$

\section{Introduction}

In the past decade, "classical" neuropeptides such as oxytocin (OT) and arg-vasopressin (AVP) have been detected within thymic tissue of several species including mice, rats and humans (Argiolas et al. $1990 \mathrm{~b}$; Geenen et al. 1986; Markwick et al. 1986). These findings were made by means of immunocytochemistry (Moll et al. 1988; Robert et al. 1991) and further substantiated by radioimmunoassay studies (Geenen et al. 1986; Argiolas

Correspondence to: $\mathrm{M}$. Wiemann et al. 1990b), which showed that the relative amount of oxytocin extractable from the organ was higher than that commonly found within body fluids (Geenen et al. 1986). Additionally, dot-blot investigations revealed OTand AVP-mRNAs in thymic tissue (Rehbein et al. 1986; Geenen et al. 1987). The molecular identity of thymic and brain-produced OT was also affirmed by coelution studies on different HPLC-columns (Argiolas et al. $1990 \mathrm{~b}$ ). Together, these investigations provide convincing evidence for a synthesis of OT by certain thymic epithelial cells.

In contrast to neurons of the supraoptic or paraventricular nucleus, OT, AVP and their related neurophysins occur within the same cells in the thymus (Geenen et al. 1991). These cells also stain for a ganglioside (Geenen et al. 1989) found in neuroendocrine cells and cells of the neural crest (Haynes et al. 1983); they were, therefore, regarded as neuroendocrine elements (Geenen et al. 1987). Interestingly, thymic nurse cells (Wekerle and Ketelsen 1980) also contain immunoreactive OT (Geenen et al. 1988) that may help to promote the growth or differentiation of enclosed thymocytes (Geenen et al. 1991). The assumed secretion of OT and AVP from thymic epithelial cells is further supported by the presence of highly selective OT-receptors in membrane preparations of thymic tissue (Elands et al. 1988) and on thymocytes (Elands et al. 1990).

The number of thymic OT-receptors and their $\mathrm{K}_{\mathrm{D}^{-}}$ values can be modulated by estrogen and, less pronounced, by testosterone (Caldwell et al. 1991). These results point to complex hormonal regulation mechanisms involving thymic OT, especially during phases of increased sex steroid levels, e.g., during pregnancy. The regulation of thymic OT appears even more complicated as judged by some evidence for the existence of a hypothalamic (Argiolas et al. 1990 b) or thyroid control (Argiolas et al. 1990a).

In general, thymocytes can respond to O'T by enhanced glucose uptake (Goren et al. 1984), DNA synthesis and mitotic activity (Whitfield et al. 1969). Also, interleukin 2-like actions of OT on lymphatic cells have 
been demonstrated in vitro (Johnson and Torres 1985; Torres and Johnson 1988). Thus, stimulating immunomodulatory effects of OT in vivo are likely. Since it is still unclear how epithelial cells present OT to thymocytes and whether a paracrine secretion is involved, the present ultrastructural study was performed to elucidate how OT may be stored and released from epithelial cells of the thymus.

\section{Materials and methods}

\section{Animals}

For all studies mice (outbred strain NMRI) of both sexes aged 4 to 16 weeks were used. Animals were kept under continuous light-dark cycle (lights on at $0600 \mathrm{~h}$, off at $2000 \mathrm{~h}$ ) at $21-23^{\circ} \mathrm{C}$. Food and water were available ad libitum.

\section{Antibodies}

Two rabbit antibodies against oxytocin were used in this study. K31 (generously provided by G. Jirikowsky, MPI für Psychiatrie, Munich, Germany) showed staining specificities identical to K23 (Jirikowsky et al. 1988; G. Jirikowsky, personal comunication) and showed no detectable cross-reactivity with AVP, arg-vasotocin and neurophysin $(\mathrm{Np})$. The second anti-oxytocin antibody, OT-Ab, was from Ferring (Kiel, Germany). Cross-reactivity with AVP or Np was not detected by preabsorption studies. Rabbit anti-Np was originally raised by Dr. H. Schwandt (Munich, Germany) and reacted with both Np I and II. Sheep anti-rabbit antibody and rabbit peroxidase-anti-peroxidase (PAP) complex were from Sigma.

\section{Tissue preparation}

Animals were anesthetized with sodium pentobarbital $(80 \mathrm{mg} / \mathrm{kg}$ ) and transcardially perfused with saline followed by the appropriate fixation fluid. For pre-embedding studies with K31, 4\% paraformaldehyde, $0.5 \%$ glutaraldehyde in $0.1 \mathrm{M}$ sodium phosphate buffer (NaPP), pH 7.2-7.4, was used. For postembedding procedures with anti-Np, the former fixative contained $2 \%$ glutaraldehyde, whereas glutaraldehyde was omitted when OT-Ab was used.

\section{Culture of thymic epithelial cells}

Primary cultures of thymic tissue were prepared from 4-week-old mice according to Hiramine et al. (1990) with minor modifications. Tissue fragments were digested with Versene (Gibco) containing $0.05 \%$ trypsin for $30 \mathrm{~min}$ at $37^{\circ} \mathrm{C}$. Digestion was stopped with Eagle's minimal essential medium (MEM, Gibco) containing 10\% fetal calf serum (FCS), $100 \mathrm{U}$ penicillin, $100 \mu \mathrm{g} / \mathrm{ml}$ streptomycin and $50 \mathrm{U}$ DNAse I (Boehringer, Mannheim, Germany). Cells were passed through nylon gaze, sedimented and afterwards cultured in Waymouth's medium containing $2 \%$ FCS for 2 days at $37^{\circ} \mathrm{C}$, $6 \% \mathrm{CO}_{2}$, and $100 \%$ humidity. Medium was then replaced by MEM-D-valine (Gibco) containing 10\% FCS, $100 \mathrm{U}$ penicillin and $100 \mu \mathrm{g}$ streptomycin.

\section{Immunocytochemistry, light-microscopical studies}

Tissue pieces of 12 animals were embedded in Epon following standard methods. Serial sections $(0.5 \mu \mathrm{m})$ were stained according to
Richardson to distinguish cortical and medullary areas. Epon was removed according to Mayor et al (1961). Slides were thoroughly washed in $20 \mathrm{mM}$ NaPP, pH 7.2, after this and all following steps. Primary antibodies were diluted 1:5000 (OT-Ab), 1:700 (K31) or $1: 500$ (anti-Np), respectively. Bound antibodies were visualized by the PAP-method using a sheep anti-rabbit antibody and a rabbit PAP-complex diluted $1: 70$ and $1: 100$, respectively. Peroxidase was stained by incubating $10 \mathrm{~min}$ in the chromogene $\left(12,5 \mathrm{mg} 3,3^{\prime} \mathrm{di}-\right.$ aminobenzidine, $10 \mu \mathrm{l} 30 \%$ hydrogen peroxide and $200 \mu 18 \%$ $\mathrm{NiCl}_{2}$ dissolved in $100 \mathrm{ml} 20 \mathrm{mM}$ sodium phosphate buffer, $\mathrm{pH}$ 7.2). Slides were washed, dried and mounted with Entellan (Merck).

\section{Electron microscopy of tissue and cultured cells}

Slices $(0.5-1 \mathrm{~mm})$ of fixed tissue were rinsed in $0.1 \mathrm{M} \mathrm{NaPP}, \mathrm{pH}$ 7.2 (used for all subsequent steps), and incubated in the same buffer containing $1.5 \% \mathrm{H}_{2} \mathrm{O}_{2}, 0.1 \% \mathrm{NaN}_{3}$ and $5 \%$ goat serum for $30 \mathrm{~min}$ in order to block endogenous peroxidase. After extensive washing, tissue was incubated for $3 \mathrm{~d}$ with $\mathrm{K} 31(1: 600), 6 \mathrm{~h}$ with the bridging antibody, and $6 \mathrm{~h}$ with the PAP-complex. Peroxidase was stained as outlined above. Tissue blocks were treated with $1 \% \mathrm{OsO}_{4}$, dehydrated in ethanol, stained en bloc with $1 \%$ uranyl acetate dissolved in $70 \%$ ethanol and finally embedded in Epon. Immunoreactive cells were identified on semithin sections and prepared for electron microscopy. Thymuses of 4 animals were investigated at the electron-microscope level and at least 3 tissue blocks per animal were sectioned. Cultured epithelial cells were stained and processed equally except that (2-hydroxypropyl)-methacrylate was ised as an intermedium instead of propylene oxide. Cells of interest were identified with the light microscope and thin-sectioned with a Reichert Ultracut microtome. Sections were viewed with a Zciss EM 10 operated at $80 \mathrm{kV}$.

\section{Controls}

Positive controls were run on semithin sections of the neurohypophysis prepared from adult NMRI mice after perfusion fixation. Specific staining of K31, OT-Ab and anti-Np was controlled by omission of the primary antibody or by using an irrelevant rabbit anti-bovine serum albumin antibody at high concentrations instead of the specific antibody. Pretreatment of K31 (1:100) with OT (Bacchem, Heidelberg, Germany) at a concentration of $10 \mu \mathrm{g} / \mathrm{ml}$ or preabsorption with CT coupled to BrCN-activated sepharose CI-4B (Pharmacia, Freiburg, Germany) abolished the property of immunostaining. Preabsorption of K31 with AVP $(10 \mu \mathrm{g} / \mathrm{ml})$ was ineffective.

\section{Results}

\section{Light microscopy}

Cells immunoreactive for OT were stained among cultured epithelial cells (Fig. 1) and within thymic tissue (Figs. 2, 3) by pre- and postembedding methods. Staining with two different antisera against OT (K31 and $\mathrm{OT}-\mathrm{Ab}$ ) gave identical patterns on consecutive semithin sections of thymic tissue (data not shown). The same cells were also stained by an anti $\mathrm{Np}$-antibody (compare Fig. 2a with Fig. 2b).

OT/Np-immunoreactive cells were found in the subcapsular cortex (Figs. 2, 4), in the thymic medulla and at the cortical medullary boundary. Their cellular processes may have diameters of less than $1 \mu \mathrm{m}$ and can therefore be studied best in semithin sections at the light- 
microscopic level. The staining intensity of single immunoreactive cells and cellular processes was found to vary throughout the cytoplasm. Densely stained patches were found within less intensely stained areas (Fig. 2c). These patches did not display clear-cut borders. Clear vacuoles, which are typically found in thymic epithelial cells, could also be identified on semithin sections. They appeared unstained within an otherwise stained cytoplasm (Fig. 2a). Thus, we obtained no evidence for an intravesicular localization of immunoreactive OT at the lightmicroscopic level.

For the subsequent electron-microscopic study (preembedding labelling) we chose $\mathrm{K} 31$, since this antibody recognizes immunoreactive cells even after fixation with small amounts of glutaraldehyde. Naturally, antibody staining was restricted to the outermost areas of the tissue blocks, from which cortical and medullary areas were selected for further investigation. Fig. 3 shows that epithelial cells of the subcapsular cortex labelled by the pre-embedding method appear equal to those labelled on semithin sections (Fig. 2a).

\section{Electron microscopy}

Structural characteristics of OT-immunoreactive epithelial cells. According to their fine structure, we distinguished three types of OT-immunoreactive epithelial cells, two of which were found in the thymic cortex and a third type in the medulla. All types of cells contained keratin filaments (Figs. 10-12, 14) and desmosomes (Fig. 9) and were, therefore, classified as epithelial cells. Due to the high variability of the cellular shape of epithelial cells their classification is based on nuclear characteristics, different degrees of cytokeratin content, and topography of the cells within the tissue.

Epithelial cells from the outer subcapsular layer (Fig. 4a) had an elongated nucleus, which was filled with fine fibrillar chromatin. Electron-dense heterochromatin occurred only sparsely. The major portion of such cells was spread out beneath the thymic capsule, while fine processes extended into the deeper cortex. A well-developed Golgi apparatus and numerous small vesicles were detectable (Fig. 4b). Single cytokeratin filaments were frequent, while bundled cytokeratin threads were absent in these cells.

In the deeper cortex, immunoreactive cells with smaller and ovoid nuclei were found; these nuclei lacked apparent heterochromatin (Fig. 11a). Bundles of cytokeratin filaments were frequently observed within the branching cellular processes (Figs. 10, 11 a), which often surrounded cortical thymocytes (Fig. 11a).

In the medulla, OT-immunoreactive cells displayed a more irregular-shaped nucleus with a prominent nucleolus and a dense layer of marginal heterochromatin (Fig. 12b). Large clear vacuoles were highly abundant in these cells (Fig. 12a), which also contained bundled cytokeratin filaments (Fig. 12b).

In all cells, immunoreactive OT was restricted to the cytoplasm and the staining pattern appeared similar.
Consequently, results from the different cell types were taken together and are outlined below.

Localization of immunoreactive OT in epithelial cells in the tissue. The majority of the electron-dense reaction product was dispersed diffusely or in patches in the cytosol (Figs. 4b-10, 12-15). Areas of increased immunoreactivity were found close to the cytoplasmic membrane (Fig. 8) but also in the cytoplasm proper (Figs. 4b, 14). These accumulations could not be related to cellular structures of either the labelled epithelial cell or any adjacent thymocyte. Terminal portions of epithelial processes did not display increased staining intensities or an increased number of vesicles (Fig. 6). In very few cases electron-dense patches were found that can be interpreted as vesicles with a labelled lumen (Figs. 7, 12a).

Dense reaction product adhered closely to many vesicle membranes encircling a clear, electron-translucent lumen. These vesicles ranged in diameter from 80 to $170 \mathrm{~nm}$ and were found in proximity to the unlabelled Golgi apparatus (Fig. 4b) and in the cytoplasm of epithelial processes (Figs. 5-7). Since labelled and unlabelled vesicles occurred in close proximity, we conclude that this pattern reflects the in-vivo distribution of the antigen rather than a DAB-reaction product adhering to membrane-bounded cytosolic compartments. Immunostained material was also found adhering to tubular structures in epithelial processes (Fig. 5), to the plasmalemma (Figs. 5-7), and to outer membranes of mitochondria (Fig. 4b).

Figs. 5-11. OT-immunoreactive epithelial cells of the thymic cortex

Fig. 5. Immunoreactive process of an epithelial cell with fine ramifications (arrows) interdigitating between tightly packed cortical thymocytes $(T)$. The staining delineates membranes of small vesicles, membrane-bounded tubules and the plasma membrane. $B a r: 1 \mu \mathrm{m}$; $\times 23000$

Fig. 6. The end-piece of an epithelial process contacts a thymocyte. At this point there is no increase in staining intensity and an acclmulation of vesicles is missing. Bar: $1 \mu \mathrm{m} ; \times 23000$

Fig. 7. Highly vesiculated area of an OT-immunoreactive epithelial process. Some vesicles (arrowheads) display distinct membrane labelling. Note a single densely stained body (diameter: $250 \mathrm{~nm}$, arrow). Bar: $1 \mu \mathrm{m} ; \times 21000$

Fig. 8. The diffuse labelling of the cytosol appears concentrated at a circumscribed site of the cytoplasmic membrane (open arrows) and faces a structure of unknown nature. Bar: $1 \mu \mathrm{m} ; \times 21000$

Fig. 9. Immunoreactive (left) and non-reactive epithelial cell connected by a desmosome; arrows cytoplasmic plaques in both cells. Bar: $0.5 \mu \mathrm{m} ; \times 43000$

Fig. 10. Note prominent bundles of unlabelled keratin filaments (arrows) indicating that cytokeratins are not necessarily linked to immunoreactive OT. Bar: $1 \mu \mathrm{m} ; \times 12500$

Fig. 11 a. Immunoreactive epithelial cell partly surrounding thymocytes $(T)$ in the deeper cortex. The ovoid nucleus $(N)$ lacks apparent heterochromatin. Most soluble components were lost from the cytoplasm due to the 3 -day staining procedure. The retained cytoskeleton is composed of heavily labelled cytokeratin filaments, some of which are organized into prominent bundles (arrow). Bar: $1 \mu \mathrm{m}$; $\times 18000$. b Spots of the DAB-reaction product (arrows) are attached to keratin filaments. $B a r: 0.2 \mu \mathrm{m} ; \times 42000$ 

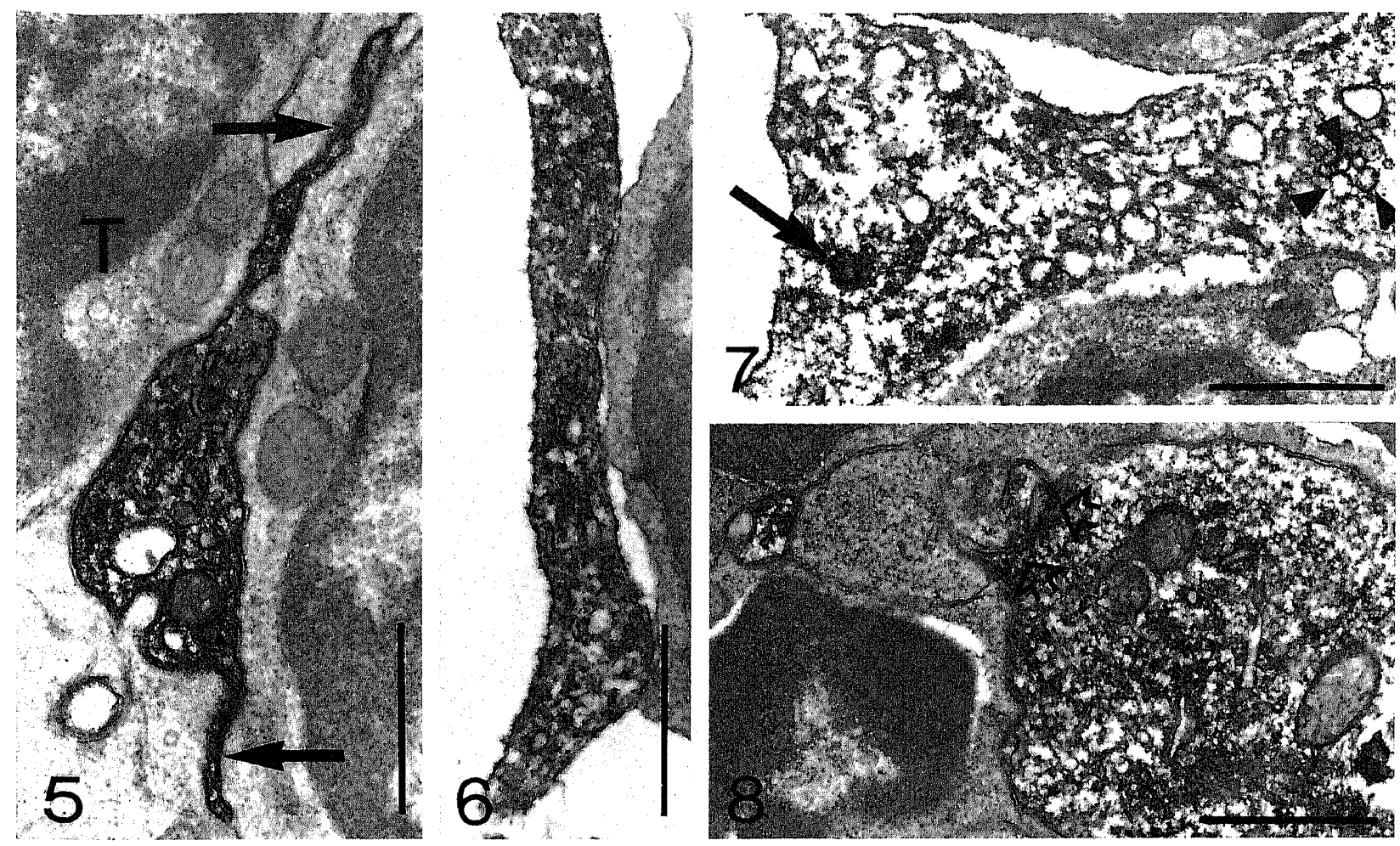

1.

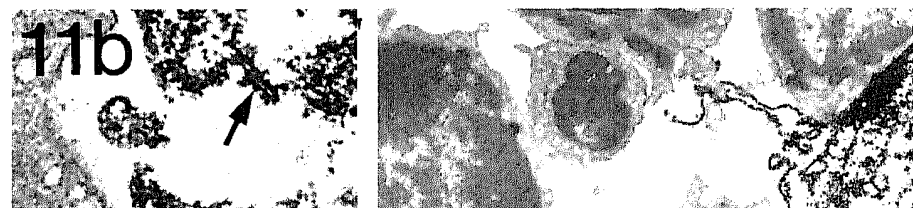

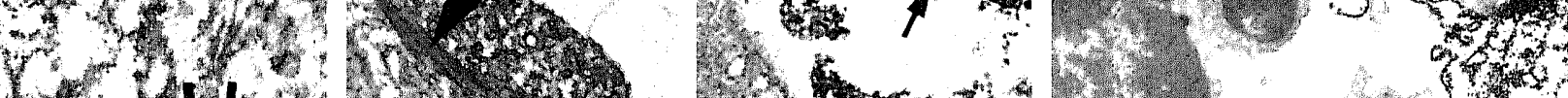
W.t. 1. and

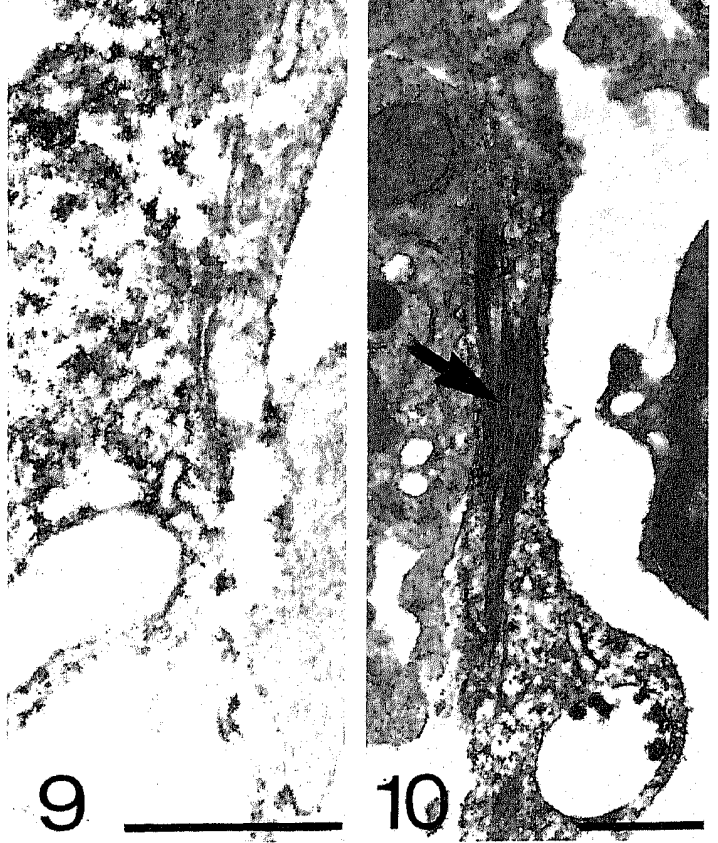

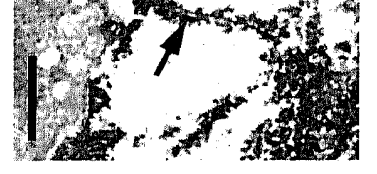

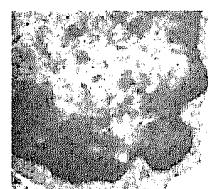

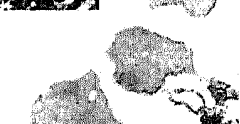
(3)

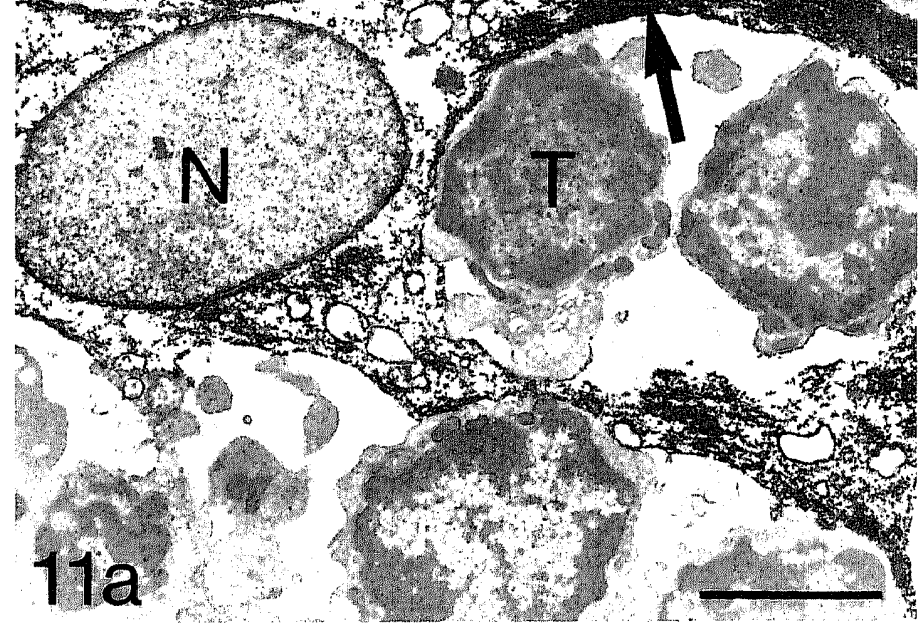



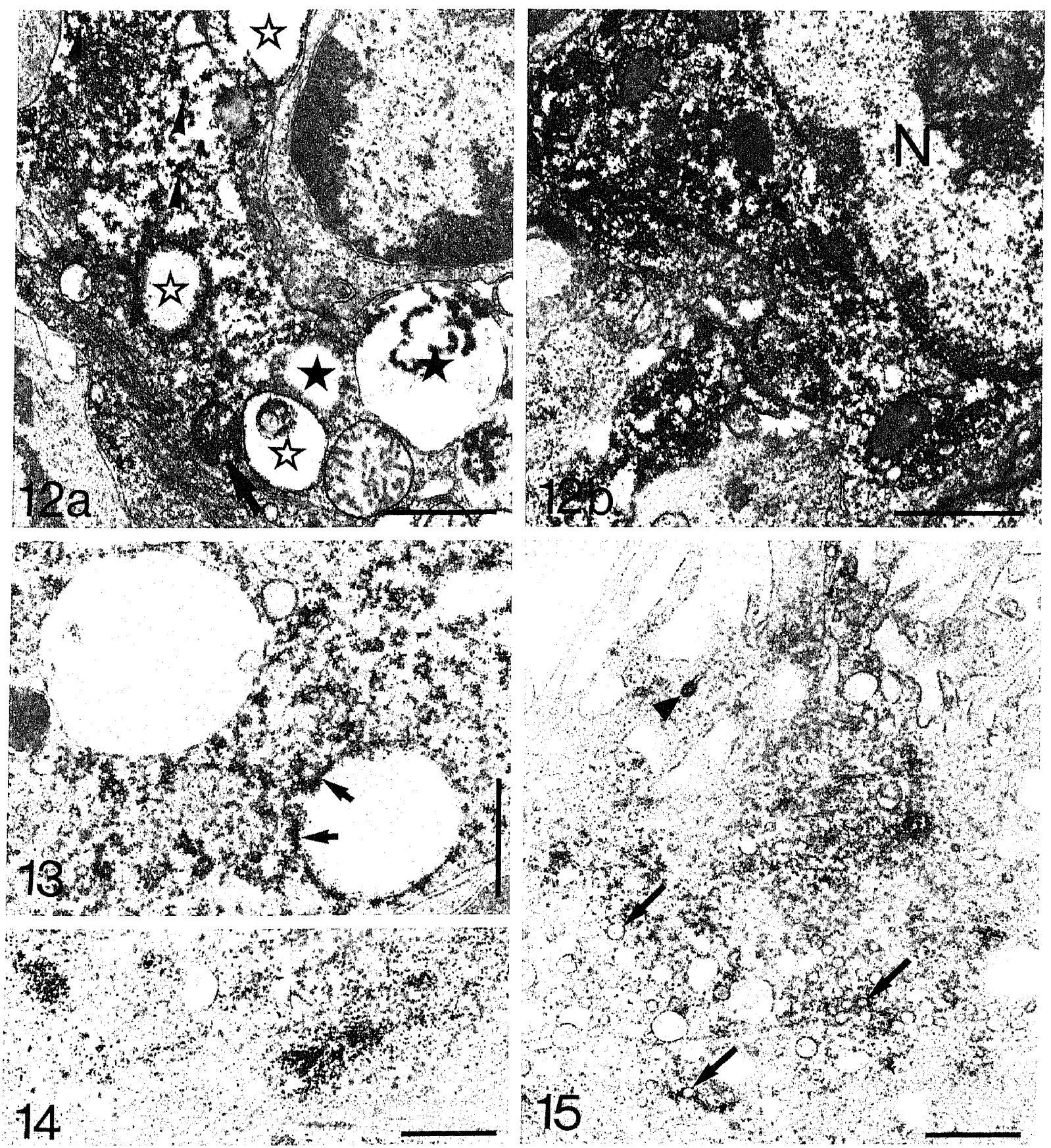

Figs. 12, 13. OT-immunoreactive epithelial cells from the thymic medulla

Fig. 12. a Note numerous large clear vacuoles. Some of them are stained at their periphery and/or their membranes (marked by open asterisks), while others are bordered by unlabelled membranes (filled asterisks). Electron-opaque material can be found within both types of inclusions. Arrow points to a single completely labelled vacuole. OT-immunoreactive accumulations $(80-100 \mathrm{~nm}$ in diameter) possibly representing vesicles (arrowheads) are scattered throughout the cytoplasm. Bar: $1 \mu \mathrm{m} ; \times 17500$. b Portion of irregularly shaped nucleus $(N)$ characteristic for this cell type. The nucleolus is prominent and a dense layer of marginal heterochromatin is visible. Bar: $1 \mu \mathrm{m} ; \times 20500$

Fig. 13. The membrane of a large clear vacuole is associated with electron-dense DAB-reaction product (arrows); it appears to form a layer consisting of electron-dense particles. Bar: $0.5 \mu \mathrm{m} ; \times 36500$

Figs. 14, 15. Electron micrographs of OT-immunoreactive epithelial cells from a primary culture at day 5 of cultivation

Fig. 14. Accumulations of OT-immunoreactivity within the cytoplasm are not related to distinct cellular structures. Bar: $1 \mu \mathrm{m}$; $\times 14000$

Fig. 15. Some portions of a highly vesiculated cytoplasmic area are stained and many vesicle membranes are associated with DABreaction product (arrows). A heavily stained membrane-bounded tubule is located close to the plasma membrane (arrowhead). Bar: $1 \mu \mathrm{m} ; \times 14000$ 
Large clear vacuoles, which were found to be unlabelled in semithin sections, usually displayed a clear lumen at the electron-microscopic level. However, many of them (especially in the medulla) were densely stained in their periphery (Fig. 12a) and/or at the aspect of their luminal membrane (Figs. 12a, 13). Vacuoles with this membrane-related staining were somewhat smaller (diameter up (o $0.8 \mu \mathrm{m})$ than those with unlabelled memhranes (diameter up to $1.2 \mu \mathrm{m}$ ). This indicates that large ckar lacuoles are not homogeneous with respect to their immunoreactive OT. Furthermore, some of these vacuoles contained electron-opaque material of unknown composition that was slightly immunoreactive (Figs. 10 , (2:i1).

Immunoreactive OT was found to be attached to keratin filaments in cortical epithelial cells (Fig. 11b). This wats especially evident in damaged cells that had lost most of their cytosolic components (Fig. 11 a). Since most cytokeratin tilaments were found to be unlabelled. this finding may reflect binding properties of a special type of eytokeratin.

l.nealizution of immunoreactive OT in cultured epithelial ath. Between $5 \%$ and $10 \%$ of the cultured cells were found to be stained for immunoreactive OT (Figs. 1, 13. 14). Different cell types could be distinguished with respect to their shape after $5 \mathrm{~d}$ in culture (Fig. 1): (i) small cells with small nuclei and long, slender processes, and (ii) cells with a more widespread cytoplasm and larger and more or less centrally located nuclei. Electron microscopy again revealed that immunoreactive OT was mainly alssociated with vesicular membranes or membrane-bounded tubules (Fig. 15) or was located in the cytosol without any relation to corpuscular cellular inclusions (Fig. 14). Cytokeratin-containing structures were found to be unlabelled (Fig. 14).

\section{Discussion}

The known subset of thymic epithelial cells expressing immunoreactive OT was identified and further characterized by means of immuno-electron microscopy. We distinguish 3 types of OT-immunoreactive epithelial cells in situ and at least two types in primary cell culture. Due to fine structural characteristics 6 types of thymic epithelial cells are generally distinguished (for review, see von Gaudecker 1991). Following this classification, the subeapsular and perivascular epithelium (type 1), the cortical epithelium with round, euchromatic nuclei (type $2)$, and the medullary epithelium with irregular, heterochromatic nuclei (type 4) are immunoreactive for OT. These findings extend our knowledge on the diversity of OT-immunoreactive cells, which are supposed to serve different functions during $\mathrm{T}$-cell maturation. It will be of great interest to elucidate how the same peptide is involved in cortical (early) and medullary (late) maturation steps. Since we did not detect striking differences in the intracellular labelling pattern of immunoreactive OT, it seems likely that the mode of secretion or its presentation to thymocytes is not modified within the organ.
Since hypothalamic neurons release OT from densecore vesicles (Pow and Morris 1989) we anticipated finding similar vesicles also within thymic epithelial cells. However, our results do not support the occurrence of special vesicles responsible for a constant or inducible secretion. We obtained only a few small labelled vesicles (Fig. 7,12 b) or some large clear vacuoles, which were labelled at their periphery (Fig. 12a). The bulk of immunoreactive OT was found in the cytosol or adhered to membranes of vesicles or to the plasma membrane. Since similar findings were obtained with cultured epithelial cells (which are rapidly accessible to the fixative) we conclude that immunoreactive OT is located in the cytosol rather than in vesicles. Furthermore, if cytosolic immunoreactive OT was artificially released from vesicles, this would hardly lead to a completely unstained lumen. We also exclude that our antibodies have failed to penetrate the vesicular membrane since Triton X-100 added to the primary antibody did not change the obtained distribution pattern (data not shown).

Nevertheless, we focused on large clear vacuoles since they have long been intimated as secretory vesicles (Clark 1966; Porter and Bonneville 1973). However, recent work from our laboratory has shown that these vacuoles may also contain exogenous proteins (Wiemann and Ehret, in preparation). Thus, immunoreactive peptides localized in these vacuoles may be of either endogenous or exogenous origin, which further complicates the subcellular localization of peptides suspected to be secreted in a paracrine fashion. Thymosin $\alpha 1$ and thymulin, both of which can be immunostained in the cytosol, also occur in large clear vacuoles (Fabien et al. 1988; Auger et al. 1987). In vitro, this localization was more pronounced in aged cultures (Fabien et al. 1988). Since the authors were unable to observe exocytosis of these vacuoles, they proposed that these vacuoles only store thymosin, which is then secreted from the cytoplasm by an unknown mechanism. Recently, a nonclassical secretory pathway of thymic peptides by ATP-driven membrane translocators has been suggested for $\alpha$-prothymosin, parathymosin and IL-1 (for review, see Kuchler and Thorner 1992). All of these peptides are found in thymic epithelial cells from which they are secreted, although hydrophobic signal sequences are absent. Thus, thymic epithelial cells are likely to secrete peptides that are not bound for intravesicular localization. Although this idea is speculative, it may also apply to immunoreactive OT found to be preferentially localized within the cytosol.

The predominant non-vesicular localization of immunoreactive OT in thymic epithelial cells is surprising and suggests that it may represent a part of the OT-precursor containing the OT epitopes. The existence of immunoreactive OT in thymic tissue has been confirmed by many different antibodies against OT and Np. Recently, a study with monoclonal antibodies against OT (Burgeon et al. 1991) provided some evidence that thymic immunoreactive OT may be different from hypophyseal OT with respect to the N-terminal tripeptide (Robert et al. 1991; Geenen et al. 1991). On the other hand, the Cterminal cyclic hexapeptide of OT was recognized in 
thymic epithelial cells. Vasotocin sharing this cyclic hexapeptide with OT also mimicked the effect of IL-2 on certain lymphocytes (Johnson and Torres 1985). Thus, a peptide representing a component of the OT-molecule might be of immunological significance within the thymus if it is presented to lymphocytes.

We cannot rule out that OT and incompletely processed OT coexist in thymic epithelial cells, which would explain the conflicting data resulting from immunocytochemistry and HPLC-studies (Argiolas et al. 1990 b). Although most biochemical data substantiate the existence of thymic OT, a final proof should rely on the sequence of the appropriate thymic mRNA whose cloning is still pending.

Immunoreactive OT was associated with cytokeratin filaments and different types of membranes. An interesting parallel comes from a AVP/OT/Np-related, membrane-targeted peptide reacting with anti-AVP antibodies (Rosenbaum et al. 1990). Although all of these associations initially appear to be unspecific, they might be of biological significance. The occurrence of highly labelled cytosolic areas (Figs. 8, 15) and the close proximity of labelled and unlabelled vesicles (Figs. 4b, 13, 14) suggest that immunoreactive OT is targetted to cytoplasmic structures that may be involved in the release of the peptide.

In conclusion, our results do not substantiate a paracrine secretion of OT by means of immunoreactive vesicles as described for brain tissue. It seems possible that OT adheres to the luminal side of large clear vacuoles and is released when these vacuoles fuse with the cellular membrane, although this process has not been observed in the present study. Also, a stimulation of thymocytes by means of an intimate cell-cell-contact seems possible, and it remains to be tested whether epithelial cells that present antigens to T-cells (Mizuoshi et al. 1992) can also present OT to OT-receptor-bearing cells of the immune system without signs of secretion. However, our data cannot exclude that epithelial cells release OT into the interstitium. The great similarity of OT-immunoreactivity in cultured and tissue-bound cells may provide an answer to this question when using suitable cell culture models.

Acknowledgements. This study was supported by the VolkswagenStiftung, project I/65 793. The authors want to thank Mrs. A. Jürgens and Mrs. A. Schmidt-Häberlein for excellent technical assistance.

\section{References}

Argiolas A, Gessa GL, Melis MR, Stancampiano R, Vaccari A (1990a) Effects of neonatal and thyroid dysfunction on thymic oxytocin. Neuroendocrinology 52:556-559

Argiolas A, Melis MR, Stancampiano R, Mauri A, Gessa GL (1990 b) Hypothalamic modulation of immunoreactive oxytocin in the rat thymus. Peptides $11: 539-543$

Auger C, Stahli C, Fabien N, Monier J-C (1987) Intracellular localization of thymosin alpha 1 by immunoelectron microscopy

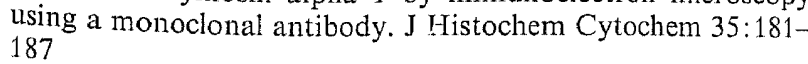

Burgeon E, Chapleur M, Schoenen J, Remichius D, Legros J-J, Geenen V, Robert F (1991) Monoclonal antibodies to oxytocin: production and characterization. J Neuroimmunol 31:235-244
Caldwell JD, Walker CA, Noonan LR, Jirikowsky GF, Peterson G, Pedersen CA, Mason GA (1991) Changes in thymic oxytocin receptors during early development and in steroid treated adult rats. Prog Neuroendocrin Immunol 4:228-233

Clark SL Jr (1966) Cytological evidences of secretion in the thymus. In: Wolstenholme GEW, Porter R (eds) The thymus: experimental and clinical studies. Ciba Foundation Symposium, Little Brown, Boston, p 3

Elands J, Resink A, De Kloet ER (1988) Oxytocin receptors in the rat thymic gland. Eur J Pharmacol 151:345-346

Elands J, Resink A, De Kloet ER (1990) Neurohypophyseal hormone receptors in the rat thymus, spleen, and lymph nodes. Endocrinology 126:2703-2710

Fabien N, Auger C, Monier J-C (1988) Immunolocalization of thymosin alpha 1 , thymopoetin and thymulin in mouse thymic epithelial cells at different stages of culture: a light and electron microscopic study. Immunology 63:721-727

Geenen V, Legros J-J, Franchimont P, Baudrihaye M, Defrense M-P, Boniver J (1986) The neuroendocrine thymus: coexistence of oxytocin and neurophysin in the human thymus. Science 232: $508-511$

Geenen V, Legros J-J, Franchimont P, Defrense M-P, Boniver J, Ivell R, Richter D (1987) The thymus as a neuroendocrine organ. Synthesis of vasopressin and oxytocin in human thymic epithelium. Ann NY Acad Sci 496:56-66

Geenen V, Defrense M-P, Robert F, Legros J-J, Franchimont P, Boniver $J$ (1988) The neurohormonal thymic microenvironment: Immunocytochemical evidence that thymic nurse cells are neuroendocrine cells. Neuroendocrinology 47:365-368

Geenen V, Robert F, Defrense M-P, Boniver J, Legros J-J, Franchimont P (1989) Neuroendocrinology of the thymus. Horm Res $31: 81-84$

Geenen V, Robert F, Martens H, Benhida A, De Giovanni G, Defrense M-P, Boniver J, Legros J-J, Martial J, Franchimont $P(1991)$ Biosynthesis and paracrine/cryptocrine actions of 'self" neurohypophysial-related peptides in the thymus. Mol Cell Endocrinol 76:C27-C31

Goren JH, Okabe T, Lederis K, Hollenberg MD (1984) Oxytocin stinulates glucose oxidation in rat thymocytes. Proc West Pharmacol Soc $27: 461-463$

Haynes BF, Shimizu K, Eisenbarth G (1983) Identification of human and rodent thymic epithelium using tetanus toxin and monoclonal antibody A2B5. J Clin Invest 71:9-14

Hiramine C, Hojo K, Koseto M, Nakagawa T, Mukasa A (1990) Establishment of a murine thymic epithelial cell line capable of inducing both thymic nurse cell formation and thymocyte apoptosis. Lab Invest 62:41-54

Jirikowsky GF, Caldwell JD, Pedersen, Stumpf WE (1988) Estradiol influences oxytocin-immunoreactive brain systems. Neuroscience $25: 237-248$

Johnson HM, Torres BA (1985) Regulation of lymphokine production by arginine vasopressin and oxytocin: modulation of lymphocyte function by neurohypophyseal hormones. J Immunol 135:773s-775s

Kuchler K, Thorner J (1992) Secretion of peptides and proteins lacking hydrophobic signal sequences: The role of adenosine triphosphate-driven membrane translocators. Endocr Rev 13:499-514

Markwick AJ, Lolait SJ, Funder JW (1986) Immunoreactive arginine vasopressin in the rat thymus. Endocrinology 119:16901696

Mayor HD, Hampton JC, Rosario B (1961) A simple method for removing the resin from epoxy-embedded tissue. J Cell Biol 9:909-910

Mizuoshi M, Kasai M, Kokuho T, Kakiuchi T, Hirokawa K (1992) Medullary but not cortical thymic epithelial cells present soluble antigens to helper T cells. J Exp Med 175:1601-1605

Moll UM, Lane BL, Robert F, Geenen V, Legros J-J (1988) The neuroendocrine thymus. Histochemistry $89: 385-390$

Porter KR, Bonneville MA (eds) (1973) Fine structure of cells and tissues, 4th edn. Lea and Febiger, Philadelphia, pp 149-150 
Pow DV, Morris JF (1989) Dendrites of hypothalamic magnocellular neurons release neurohypophysial peptides by exocytosis. Neuroscience 32:435-439

Rehbein M, Hillers M, Mohr E, Ivell R, Morley S, Schmale H, Richter D (1986) The neurohypophyseal hormones vasopressin and oxytocin. Biol Chem Hoppe Seyler 367:695-704

Robert F, Geenen V, Schoenen J, Burgeon E, De Groote D, Defrense MP, Legros JJ, Franchimont P (1991) Colocalization of immunoreactive oxytocin, vasopressin and interleukin-1 in human thymic epithelial neuroendocrine cells. Brain Behav Immun $5: 102-115$

Rosenbaum LC, Neuwelt EA, Van Tol HHM, Loh YP, Verbalis JG, Hellström I, Hellström KE, Nilaver G (1990) Expression of neurophysin-related precursor in cell membranes of a small lung carcinoma. Proc Natl Acad Sci USA 87:9928-9932

Torres BA, Johnson HM (1988) Arginine vasopressine (AVP) replacement of helper cell requirement in IFN- $\tau$ production. $J$ Immunol 140:2179-2183

Von Gaudecker B (1991) Functional histology of the human thymus. Anat Embryol 183:1-15

Wekerle H, Ketelsen U-P (1980) Thymic nurse cells - Ia bearing epithelium involved in $\mathrm{T}$ lymphocyte differentiation? Nature 283:402-404

Whitfield JF, Perris AD, Youdale T (1969) The calcium mediated promotion of mitotic activity in rat thymocyte populations by growth hormone, neurohormone, parathyroid hormone and prolactin. J Cell Physiol 73:203-211 